\title{
THE EFFECT OF GOOD CORPORATE GOVERNANCE TOWARDS IDIOSYNCRATIC RISK
}

\author{
Cintya Yuliana Limantara \\ Faculty of Business and Economics, University of Surabaya \\ cintyalimantara18@gmail.com \\ Werner R. Murhadi \\ Faculty of Business and Economics, University of Surabaya \\ werner@staff.ubaya.ac.id \\ Liliana Inggrit Wijaya \\ Faculty of Business and Economics, University of Surabaya \\ liliana@staff.ubaya.ac.id
}

Received: January, 2020; Accepted: June, 2020; Published: September, 2020

DOI: https://doi.org/10.24123/jmb.v19i2

\begin{abstract}
This study aims to analyze the effect of good corporate governance towards idiosyncratic risk as a proxy with corporate governance variable as board size, independent director, women, firm size, firm performance, and firm age. The object of this study uses companies listed in the Indonesia Stock Exchange and Philippine Stock Exchange using agency theory. This study uses quantitative approach and multiple linear regression to analyze the data. The target populations of this study are manufacturing companies that listed in Indonesia Stock Exchange and Philippine Stock Exchange in 2014-2018 which are equal to 615 and 200 year observations. The results in Indonesia showed that board size, women, and firm age had negative effect on idiosyncratic risk. On the other hand, firm size do not show the effect on idiosyncratic risk and firm performance had positive effect on idiosyncratic risk. However, the results in Philippine showed that board size had positive effect on idiosyncratic risk. While, women and firm size do not show the effect on idiosyncratic risk but firm performance and firm age had negative effect on idiosyncratic risk.
\end{abstract}

Keywords: good corporate governance, idiosyncratic risk, agency theory.

\begin{abstract}
Abstrak
Penelitian ini bertujuan untuk menganalisis pengaruh dari good corporate governance terhadap idiosyncratic risk dengan variabel corporate governance, seperti: board size, independent director, women, firm size, firm performance, dan firm age. Objek penelitian ini menggunakan perusahaan manufaktur yang terdaftar di Bursa Efek Indonesia dan Bursa Efek Filipina menggunakan teori keagenan. Penelitian ini menggunakan pendekatan kuantitatif dan metode regresi linear berganda untuk menganalisis data. Target populasi dari penelitian ini adalah perusahaan manufaktur yang terdaftar pada Bursa Efek Indonesia dan Bursa Efek Filipina periode 2014-2018 dengan jumlah 615 dan 200 observasi. Hasil penelitian di Indonesia menunjukkan bahwa board size, women, dan firm age berpengaruh negatif terhadap idiosyncratic risk. Di sisi lain, firm size tidak menunjukkan pengaruh terhadap idiosyncratic risk dan firm performance berpengaruh positif terhadap idiosyncratic risk. Namun, hasil
\end{abstract}


penelitian di Filipina menunjukkan bahwa board size berpengaruh positif terhadap idiosyncratic risk. Sedangkan, women dan firm size tidak menunjukkan pengaruh terhadap idiosyncratic risk, tetapi firm performance dan firm age berpengaruh negatif terhadap idiosyncratic risk.

Kata Kunci: good corporate governance, idiosyncratic risk, teori keagenan.

\section{INTRODUCTION}

The rigorous business competition encourages the company to experience significant developments in regard to performance and risks that the company should look out for In this case, the company should pay attention to good corporate governance with the aim of maximizing shareholder's wealth by paying attention to the risks arising from the investments. As for the board of commissioners who act to monitor the performance of directors in carrying out corporate responsibilities as well as protecting the interests of shareholders to be expected by investors ' return is achieved. The role of this board of commissioners in the company is important in which the decision made by the board of commissioners cannot be changed and collective collegial. This makes the role of the board of commissioners influential and a major determiner in making company decisions.

Chong et al. (2018) found that Board size and Independent directors had no effect. Women has a positive effect, Firm size has no effect, ROA and Firm age have a negative effect. While other studies conducted by Koerniadi et al. (2014) found that Board size has a negatively influential, Independent director has no effect, Firm size has a negative effect, ROA has no effect. Zhang et al. (2018) in his research gave different results that Board size had a negative effect, Independent director had no effect, Firm size, ROA, and firm age had no effect. Meanwhile, study of Chakraborty et al. (2018) resulted in Board size, Independent director, Women, and ROA have negative effect. Based on the gaps found in the research results above, research on the influence of good corporate governance is conducted against idiosyncratic risk in manufacturing companies listed on the Indonesia Stock Exchange and the Philippine Stock Exchange period 2014-2018.

Effect of board size towards idiosyncratic risk. Board size is the number of commissioners in a company. Mathew et al. (2016) who also found that board size had a negative effect on idiosyncratic risk. This is related to decision making in the company, where the large number of commissioners, less compromise between the board of commissioners related to the decision, while the number of small commissioners tend to have a big risk because interaction between the board of commissioners can be done easily. As a result, the compromise between commissioners is getting higher in the company. Singh \& Davidson (2003) also argued that the increasingly large number of the board of commissioners, the function of the board of commissioners as a monitor in the company became ineffective. In this case it shows that the larger the number of commissioners, the smaller the risk faced by the company. $\mathrm{H} 1$ : Board size is negatively related to idiosyncratic risk.

The influence of independent directors on idiosyncratic risk. Ujiyanto et al. (2007) argued that independent Commissioners may act as intermediary in disputes between internal managers and supervise management policies and advise management, so that with independent commissioners, the risk of the company is getting smaller. Jensen \& Mecking (1976) explained that the larger the number of independent commissioners, the smaller the risk of the company as independent commissioners can supervise and control the actions of the directors. Kilic \& Kuzey (2016) found that independent commissioners had a negative influence on idiosyncratic risk because 
independent commissioners could maintain a different perspective as a control mechanism against the behavior of a free manager and the number of independent commissioners that many would have an impact on good supervision, resulting in increased corporate performance. In this case, it can be indicated that the larger the number of independent commissioners, the smaller the risk of the company. Linck et al. (2008), independent director has the ability, knowledge, and expertise for the company at the same time related to the emergency decision making, so that the Independent Commissioner precisely reduce the risk of the company. H2: Independent Director has a negative effect on idiosyncratic risk.

The effect of women on idiosyncratic risk. Women is the number of female commissioners in the company. Croson \& Gneezy (2009) stated that the women's commissioners are more risk-taking than men in making company decisions. In this problem, it shows that the more the number of female commissioners in the company, then the smallest of the company's risk because women are more acting as risk averse in making decisions. De Cabo et al. (2012) and Dowling et al. (2012) stated that the presence of women leaders in investment decisions and corporate organizational profiles indicated that women are more at risk for reducing the company's risk. In this case it shows that the greater the number of female commissioners, the smaller the risk facing the company (Adams \& Funk 2011). Women's commissioners also reduce the risk of the company because women are included in the risk averse (avoiding risk) when compared to men in financial decision making that might affect the allocation of corporate resources (Jianakoplos \& Bernasek 1998). H3: Women has a negative effect on idiosyncratic risk.

The effect of firm size on idiosyncratic risk. Firm size is the size of the company that is described by the total assets owned by the company Murhadi (2013) stated that the size of the company affects negatively the stock return because a small company tends to have a higher risk than a large company, so that with the high risk high return concept, the small company has a higher expectation of return from investors. Visic \& Pervan (2012) states that large companies are under the control of directors who pursue their own interests and therefore maximize profits as the goal function of the company can be replaced with the maximization function of the directors ' interests, thereby adversely affecting the company's performance. Becker et al. (2010) stated that company's size has a negative effect on company's profitability which means when the company's size rises, it will be accompanied by a decrease in profitability variables. This is due to the tradeoff between the economics of scales of the company with the cost of the company, thus impacting the profitability of the company that resulted in the company's risk increases. H4: Firm size has a negative relationship with idiosyncratic risk.

The effect of firm performance on idiosyncratic risk. The performance of the business group is a measurement of achievement that has been achieved by the business entity indicating a good condition for a certain period. Miller and Bromiley (1990) instead of Murhadi (2013) said that the lower the performance of the company, the more likely it is to choose a project at risk with a lower profit estimate than the less risky project with the higher return expected. Naldi et al. (2007) instead of Becker et al. (2010) stated that the company's performance and risk of the company had a negative relationship because entrepreneurship activities within the family company did involve taking risks, but only at a lower level than non-family enterprises. This opinion is supported by Schulze et al. (2002) that the family company in general has a formal monitoring feature that is less leading to internal and external companies, taking risks in family companies is most likely not to take into account the risks with the heart, lack of systematic reasons, and inattention to the perspectives and opinions of external 
parties. The lack of systems, monitoring practices, and more formal control for the collection and analysis of systematic information resulted in a family company investing in the wrong project without considering the pros and cons in terms of risk. The logic shows that managers in the company is less of control and the understanding of the risks taken. Besides, the manager has little pressure to analyses and motivate alternatives for internal and external stakeholders. In other words, family companies have a greater attitude to allocate resources based on the hunch and opportunities that exist can only be accepted rationally with specific and intuitive criteria (Carney 2005: 23). H5: Firm performance has a negative relationship with idiosyncratic risk.

The effect of firm age on idiosyncratic risk. Firm age is the difference between years of observation with the year the company was founded. Agarwal \& Gort 1996 stated that the older firm age they can make knowledge, abilities, and skills obsolete and induce damage to the organization. Aging companies can reflect organizational rigidity over time. In line with that, there has been a cost increase, slowing growth, an obsolete asset as well as a declining investment and R\&D (Loderer \& Waelchli 2009). Pastor and Veronesi (2003) argue that younger companies tend to be more industryoriented and have greater uncertainty about the growth of the company in the future, so that corporate return volatility is also greater because the risks borne by the company are also great. Pastor and Veronesi (2003) argue that younger companies tend to be more industry-oriented and have greater uncertainty about the growth of the company in the future, so that corporate return volatility is also greater because the risks borne by the company are also great. In this case, the longer the company stands, the financial performance of the company precisely decreases because the company has to spend a greater cost to maintain, maintain, and update the company assets used for the operation of the company, so it impacts on the increased risk of the company. H6: Firm age has a negative relationship with idiosyncratic risk.

\section{RESEARCH METHODS}

The population in this study is all manufacturing companies in Indonesia and the Philippines period 2014-2018, while the samples used are all manufacturing companies listed on the Indonesia Stock Exchange and the Philippine Stock Exchange period 2014-2018 with sample criteria: (1) the company has complete financial statements for the 2014-2018 period, (2) companies have data for all variables, such as: total board of commissioners, independent commissioners, number of women commissioners, company size , company performance, and the company's age period 2014-2018, (3) companies have data regarding the share price for the 2014-2018 period as well as dispose of companies that do IPO, delisting, and experiencing stock suspension then the company is discarded. Based on these criteria found the dependent variable Idiosyncratic Risk with the independent variables of the board size, independent director, women, and the variable control firm size, ROA, and firm age.

The data processing methods in this study use panel data with the aim to find out how the effect of independent variables on the dependent variable. Presentation of formulas and information from formulas can be seen below:

$Y_{i t}=\beta+\beta_{1}$ Board Size $_{i, t}+\beta_{2}$ IND $_{i, t}+\beta_{3}$ Women $_{i, t}+\beta_{4}$ Firm Size $_{i, t}+\beta_{5}$ Firm Performance $_{i, t}$ $+\beta_{6}$ Firm Age i $_{\mathrm{i}, \mathrm{t}}+\varepsilon_{\mathrm{i}, \mathrm{t}}$

Where $Y$ it is the risk to the company $i$ period $t$, Board Size $i, t$ is number of commissioners in the company $\mathrm{i}$ period $\mathrm{t}$, IND $\mathrm{i}, \mathrm{t}$ is number of independent 
commissioners in company i period $t$, Women $i, t$ is number of female commissioners in company i period $t$, Firm Performance $i, t$ is performance in the company i period $t$, Firm Size i,t is size in company i period t, Firm Age $i, t$ is age at company i period $t, \alpha$ is constant coefficient, $\beta$ is the regression coefficient and $e$ is the error

\section{RESULT AND DISCUSSIONS}

The presence of multicollinearity in variable independent director variable renders the variable discarded. Table 2 and 3 show descriptive statistical results for Indonesia and the Philippines with each research variable: board size, women as independent variables, firm size, ROA, and firm age as control variables and idiosyncratic risk as dependent variables.

Table 1. Indonesian Descriptive Statistics

\begin{tabular}{|c|c|c|c|c|c|c|}
\hline & IDIO_RIS & & & & & \\
\hline & K & B_SIZE & WOMEN & F_SIZE & ROA & F_AGE \\
\hline The mean & 0.056604 & 4.242276 & 0.448780 & 28,37733 & 0.039763 & 40.83252 \\
\hline Median & 0.030787 & $3,000,000$ & 0.000000 & 28.34328 & 0.028980 & 38.00000 \\
\hline Maximum & 2.161153 & 13.00000 & 4.000000 & 33.47373 & 0.920997 & 105.0000 \\
\hline Minimum & 0.000000 & 2.000000 & 0.000000 & 20,20982 & -0.548466 & 5.000000 \\
\hline Std. Dev & 0.147163 & 1.843600 & 0.648396 & 1.841863 & 0.110303 & 17,19034 \\
\hline Skewness & 10.02379 & 1.311931 & 1.392456 & -0.642682 & 1.184983 & 1.489779 \\
\hline Kurtosis & 120.5295 & 5.216127 & 4,975419 & 6.306968 & 15,32426 & 6.042262 \\
\hline Jarque-Bera & 364261.5 & 302,2693 & 298.7366 & 322.5725 & 4036,045 & 464.6613 \\
\hline Probability & 0.000000 & 0.000000 & 0.000000 & 0.000000 & 0.000000 & 0.000000 \\
\hline Sum & 34,81149 & 2609,000 & 276.0000 & 17452.06 & 24.45453 & 25112.00 \\
\hline Sum Sq. Dev & 13,29741 & 2086901 & 258,1366 & 2082,969 & 7.470397 & 181441.7 \\
\hline Observations & 615 & 615 & 615 & 615 & 615 & 615 \\
\hline
\end{tabular}

Table 1 shows the descriptive statistics of manufacturing companies in Indonesia with an observation amount of 615 . In this study, there are variables in the form of money that have decimal units, namely idiosyncratic risk as the dependent variable and board size, women, firm size, ROA, firm age as independent and control variables. The independent variable board size, independent director, woman have a unit of people, while the firm size uses the money unit, ROA uses decimal units, and the firm age uses the unit of year. Idiosyncratic risk has an average of 0.056604 with a standard deviation of 0.147163 . The Board Size has an average of 4.242276 with a standard deviation of 1.843600 . Women has an average of 0.448780 with a standard deviation of 0.648396 . Firm size has an average of 28,37733 with a standard deviation of 1.841863 . ROA has an average of 0.039763 with a standard deviation of 0.110303 . Firm age has an average of 40.83252 with a standard deviation of 17.19034.

Table 2. Descriptive Statistics of the Philippines

\begin{tabular}{lcccccc}
\hline & IDIO_RISK & B_SIZE & WOMEN & F_SIZE & ROA & F_AGE \\
\hline The mean & 0.036674 & 6.990000 & 0.935000 & 28,82262 & -2.446915 & 40.12500 \\
Median & 0.023351 & 7.000000 & 0.000000 & 28.97295 & 0.041767 & 35.00000 \\
Maximum & 0.276202 & 13.00000 & 4.000000 & 32.31994 & 0.303903 & 99.00000 \\
Minimum & 0.006387 & $3,000,000$ & 0.000000 & 19,96878 & -497.6738 & $3,000,000$ \\
Std. Dev & 0.041263 & 2.071559 & 1.203335 & 2.006914 & 35.19388 & 23.87382
\end{tabular}




\begin{tabular}{lcccccc} 
Skewness & 3.253276 & 0.764812 & 1.027079 & -0.584004 & $-14,03575$ & 0.734197 \\
Kurtosis & 14.48255 & 3,457503 & 2.808645 & 4.110610 & 198.0031 & 2.643810 \\
& & & & & & \\
Jarque-Bera & 1451,534 & 21,24217 & 35,46819 & 21,64748 & 323452.0 & 19,02543 \\
Probability & 0.000000 & 0.000024 & 0.000000 & 0.000020 & 0.000000 & 0.000074 \\
& & & & & & \\
Sum & 7.334770 & 1398,000 & 187.0000 & 5764,524 & -489.3830 & 8025,000 \\
Sum Sq. Dev & 0.338821 & 853.9800 & 288.1550 & 801.5133 & 246483.2 & 113421.9 \\
Observations & 200 & 200 & 200 & 200 & 200 & 200 \\
\hline
\end{tabular}

Source: Eviews 10, data processed

Table 2 shows the descriptive statistics of the manufacturing company in the Philippines with an observation amount of 200 . In this research, there are variables in the form of money that have decimal units that are idiosyncratic risk as dependent variables and board size, women, firm size, ROA, firm age as independent variables and controls. The independent variable board size, independent director, woman has a unit of people, while the firm size uses the money unit, ROA uses decimal units, and the firm age uses the unit of year. Idiosyncratic risk has an average of 0.036674 with a standard deviation of 0.041263 . Board size has an average of 6.990000 with a standard deviation of 2.071559 . Women have an average of 0.935000 with a standard deviation of 1.203335. Firm size has an average of 28,82262 with a standard deviation of 2.006914. ROA has an average of -2.446915 with a standard deviation of 35.19388 . Firm age has an average of 40.12500 with a standard deviation of 23.87382 .

Hypothesis Testing Results. After going through the Chow test and the Hausman test, it is known that the best model is the fixed effect model. The equations of regression in Tables 3 and 4, show idiosyncratic risk as a dependent variable, while the board size and women as their independent variables and firm sizes, ROA, and firm age as control variables.

Table 3. Indonesian Regression Test Results

\begin{tabular}{lcccc}
\hline Variable & Coefficient & t-Statistics & Probability & Hypothesis \\
\hline C & 0.154942 & 5.950923 & $0.0000^{* * *}$ & \\
B_SIZE & -0.005280 & -4.613294 & $0.0000^{* * *}$ & - \\
WOMEN & -0.007003 & -4.299163 & $0.0000^{* * *}$ & - \\
F_SIZE & $-0,000814$ & -0.707679 & 0.4795 & - \\
ROA & 0.018138 & 7.581633 & $0.0000^{* * *}$ & + \\
F_AGE & -0.001235 & -2.183665 & $0.0295^{* *}$ & - \\
R-Squared & & & 0.641128 & \\
Adjusted R-Squared & & & 0.547541 & \\
Prob (F-Statistic) & & & 0.000000 & \\
\hline
\end{tabular}

Source: Eviews 10, data processed

Note: ${ }^{*}$ : significance at $10 \%$

** : significance at $5 \%$

*** : significance at $1 \%$

Idiosyncratic Risk $=0.154942-0.005280$ B_SIZE -0.007003 WOMEN -0.000814

$$
\text { F_SIZE + 0.018138 ROA - 0.001235 F_AGE }
$$

The equation above has a constant value of 0.154942 . The value shows that when an independent variable is 0 , the value of Idiosyncratic Risk will increase by 0.154942 . 
Table 4. Philippine Regression Test Results

\begin{tabular}{lcccc}
\hline \multicolumn{1}{c}{ Variable } & Coefficient & t-Statistics & Probability & Hypothesis \\
\hline C & 0.071472 & 3.546985 & 0.0005 & \\
B_SIZE & 0.001070 & 2.253860 & 0.0256 & + \\
WOMEN & -0.001037 & -1.464239 & 0.1452 & - \\
F_SIZE & $-0,000366$ & -1.278377 & 0.2030 & - \\
ROA & $-9.99 E-05$ & -36.56106 & 0.0000 & - \\
F_AGE & $-0,000773$ & -1.734124 & 0.0849 & - \\
R-Squared & & & 0.788866 & \\
Adjusted R-Squared & & & 0.728932 & \\
Prob (F-Statistic) & & & \\
Source: Eviews 10, data processed & & & \\
Note: " : significance at 10\% & & & \\
"* : significance at 5\% & & &
\end{tabular}

Idiosyncratic Risk $=0.071472+0.001070$ B_SIZE -0.001037 WOMEN -0.000366 F_SIZE 9.99E-05 ROA - 0.000773 F_AGE

The equation above has a constant of 0.071472 . It is significant that when the variable of independent value- 0 , then Idiosyncratic Risk will rise 0.071472 .

In Table 3, it shows the comparison of research results with research hypotheses for Indonesia. Of the two independent variables, the board size and women have significant results, while the 3 control variables there are 1 insignificant variables that are firm size, but 2 other variables are ROA and firm age have significant results. The Table 4 shows the comparison between the research results and the research hypothesis for the Philippines. Of the two independent variables, the board size has significant results and women have insignificant results, while the 3 control variables there are 1 insignificant variables that are firm size, but 2 other variables are ROA and firm age have significant results.

Board size is the number of Commissioners in the company. The research result for Indonesia on Table 3 shows that the board size has a coefficient of -0.005280 with a significance rate of 0.0000 . That is, the board size significantly negatively affects idiosyncratic risk, the more the number of commissioners in the company, the smaller the risk of the company because of coordination and cooperation between commissioners is difficult to do in decision making. The results of this study were supported by Mathew et al. (2016) who also found that board size has a negative effect on idiosyncratic risk. It is associated with decision-making in the company, where the large number of commissioners, less compromise between the board of commissioners related to the decision, while the number of small commissioners tend to have a big risk because interaction between the board of commissioners can be done easily, so that the compromise between commissioners is getting higher in the company. Chakraborty et al. (2018) states that the board size and idiorisk have negative relationship because the larger the board size, the harder it is to influence and manipulate the decision as well as the opinions between independent Commissioners and other board of directors. The results of the study for Indonesia are in accordance with the initial hypothesis which states that board size has a significant negative effect on idiosyncratic risk. The results for the Philippines in table indicate that the board size has a coefficient of 0.001070 with a significance rate of 0.0256 . This means that the board size significantly positively affects idiosyncratic risk as the 
greater number of Commissioners in the company causes the agency cost to be higher (Yermack 1996, Siddiqui et al. 2013, Singh \& Davidson 2003, Truong \& Heaney 2013, and Florackis 2008 in Garanina \& Kaikova 2015). Furthermore, communication, coordination, and managerial control become more complicated or inefficient which results in difficult decision making and takes a long time (Yermack 1996 and Eisenberg et al. 1998 in Garanina \& Kaikova 2015). Singh \& Davidson (2003) stated that the greater the number of Commissioners, the function of the Board of Commissioners as a monitor in the company became ineffective. The research results for the Philippines did not conform to the initial hypotheses stating that the board size significantly negatively affects idiosyncratic risk.

Women is the number of female commissioners in the company. The result of the study for Indonesia in table 3 shows that women have a coefficient of -0.007003 with a significance level of 0.0000 . It means that the number of female commissioners has a significant negative effect on idiosyncratic risk In this case it shows that the greater the number of female commissioners, the smaller the risk facing the company (Adams \& Funk 2011). Along with the commissioner of women, it can reduce the risk of the company for women are included in the risk-averse (to avoid the risk) when compared to men in the decision -making financially that may affect the allocation of the company's resources (Jianakoplos \& Bernasek, 1998). The opinion is supported by Croson \& Gneezy (2009) that women's commissioners more risk than men in making the company's decision. In this term, it shows the more the number of female commissioners in the company, the less the risk of the Company because women act as risk averse in decision making. De Cabo et al. (2012) and Dowling et al. (2012) stated that the presence of women leaders in investment decisions and corporate organizational profiles indicated that women are more at risk for reducing the company's risk. De Cabo et al. (2012) indicated that when a company or bank takes a significant or high risk, it is less likely to employ women in the board space because women are considered to be of insufficient quality in making the risk that a rescue action may need the company from bankruptcy. This suggests that the presence of female commissioners can reduce risk because women are more avoiding risks with the goal of making strategic decisions. Results of research for Indonesia in accordance with the initial hypothesis that women have negative influence with idiosyncratic risk. The results of research in the Philippines based on table 4 show that women have a coefficient of -0.001037 with a significance rate of 0.1452 . That is, the number of female commissioners has no effect on idiosyncratic risk. The results of this study are in line with Smith et al. (2006) that there is no influence between female commissioners and company performance because the number of female commissioners is small and it is rarely found by female commissioners at the top management level (Goddard et al. 2009) said that the industrial effect related to the number of female commissioners on company performance depends on the state and years, for example : in South Korea the trend of low economic growth has been very prominent in the manufacturing industry since 2010 (Lee et al. 2012). Stagnation for the whole industry can affect results, so the small number of female commissioners has no impact on the company's risk. This is similar to the dummy variables in the study. In line with other research beforehand (Hambrick \& Mason 1994, Canella et al. 2008; Smith et al. 1994) stated that the diversity of the top management team is reflected in heterogeneous with respect to demographics. The existence of demographic diversity reflects the cognitive diversity of top management team members who can influence the decision making process related to company performance (Finklestein \& Hambrick 1996, Jackson et al. 1991, Pegels et al. 2000a, b). This indicates that the number of commissioners of women do not have an impact 
on the company because if the companies there are commissioners of women and men, but the number of female commissioners has no impact on the company because if in the company there is a Commissioner of women and men, but the number of Commissioners of men more, then the decision of the Commissioner of Women will be rejected because the number of Commissioners of minority women and male commissioners are considered to be more daring The research results for the Philippines did not conform to the early hypotheses stating that women have significant negative effect on idiosyncratic risk.

Firm size is the size of the company described through the total assets. The research results for Indonesia in table 3 showed that the firm size has a coefficient of0.000366 with a significance rate of 0.4795 , whereas for the Philippines in table 4 indicates that the firm size has a coefficient -0.000366 with a significance level of 0.2030. That is, the size of companies in Indonesia and the Philippines has no influence on idiosyncratic risk. This result was backed by research conducted by Berggrun et al. (2016), but contrary to research conducted by Murhadi (2013) which found that the size had a significant negative influence with the return of shares. Helmi (2008) in Murhadi (2013) proved that the size of the company has no effect on the return of shares. The company's small assets are not noticed by investors in investing, but see the company's ability to return investment. Jundan (2012), ASRI \& Suwarta (2014) also showed that the company's size has no effect on the return of shares. These results show that the magnitude of a company's assets is less effective in affecting the company's performance or not even affecting the company's performance. Companies that have large assets do not guarantee the performance of the company in gaining a big profit. Another logical explanation of the results of insignificant testing suggests that the size of the company when publication of financial statements is not informative enough and is no longer an investor's concern in making investment decisions and estimating return on this period of observation. Investors think that a large company is not always able to provide a large return rate as well as vice versa, small companies do not close the possibility of providing a high return rate for its investors. The results are relevant to the research of Muhammad (2010) in Berggrun et al. (2016) stating that the size of the company has no effect on the return of shares, so the size of the company is not related to risk. The results of this study are supported by research conducted in Egypt where the economy in Egypt is in the transition or growth stage, so the size of the company has no impact on the company's performance. This indicates that the company size and risk have no relationship (Ebaid, 2009).in Murhadi (2013) in Berggrun et al. (2016) The results of the research for Indonesia and the Philippines did not conform to the early hypotheses stating that firm size was significantly negative against idiosyncratic risk.

Firm performance is a company performance measured by comparison between net income and total assets. The research results for Indonesia in table 3 showed that the firm performance has a coefficient of 0.018138 with a significance of 0.0000 . This means that the company's performance has a significant positive influence on idiosyncratic risk. Kurnia (2013) in Berggrun et al. (2016) in argues, if the company's performance is poor, then investors will not want to invest in the company because the company is considered risky and not able to provide optimum return. In this case it shows that the worse the performance of the company, impact on the company's high risk. Ganto (2008) expressed the influence of financial performance with the return of shares in a manufacturing company that shows there is a positive influence on the company's performance, where the higher the company's performance, the higher the company return. ULUPUI (2007) stated that the company's performance has a positive effect on return shares. This opinion is consistent with Modigliani and Miller (MM) 
stating that the value of the company is determined by the earnings power of the company's assets. This positive result shows that the higher the earnings power, the higher the profit margin of the company. This has an impact on increasing the company's value in terms of stock returns. The research result for Indonesia does not correspond to the initial hypothesis that the firm performance has a significant negative effect on idiosyncratic risk. The results of the study for the Philippines in table 4 showed that the firm performance had a coefficient of $-9,99 \mathrm{E}-05$ with a significance level of 0.0000 . That is, the performance of the company has a significant negative influence on idiosyncratic risk. The results of this study were supported by Miller and Bromiley (1990) in Murhadi (2013) that the lower the company's performance, the more likely it is to choose a risky project with a lower expected return than the less risky project with a higher expected return. This results in companies with low performance having to be associated with a company's risk-related return to get riskraising which implies that firms with below-average performance will experience a decrease in performance when company risks are increased. Bowman (1982) also argued that the risk-finding undertaken by problematic companies clearly impacted the increased risk of the company because the problematic company was rooted in poor corporate performance. (Schulze et al. 2002) that the company's performance had a negative relationship with the company's risk because in general the family company had a formal monitoring feature that lacked to lead to the company's internal and external, so risk-taking in family companies is most likely not to take into account the risk of being careful, lacking systematic, impartial Lack of systems, practice monitoring, and more formal control for the collection and analysis of systematic information resulted in the family companies investing in wrong projects without considering the pros and cons in terms of risk. The results of the study for the Philippines in accordance with the initial hypothesis stated that firm performance was significantly negative against idiosyncratic risk.

Firm Age is the age of the company that is calculated since the company was established. The research results for Indonesia in table 3 showed that the firm age has a coefficient 0.001235 with a significance rate of 0.0295 , while the Philippines in table 4 has a coefficient -0.000773 with a significance rate of 0.0849 . That is, the company's age in Indonesia and the Philippines has a significant negative influence on idiosyncratic risk. In this case, the longer the company stands, the financial performance of the company precisely decreases because the company has to spend a greater cost to maintain, and update the company assets used for the operation of the company, thus it impacts on the increased risk of the company. The older a company is, it can make knowledge, skills obsolete, and induce organizational damage (Agarwal \& Gort 1996 \& 2002). Aging firms can reflect organizational rigidity over time. In line with that, there has been a cost increase, slowing growth, an obsolete asset as well as a declining investment and R\&D (Loderer \& Waelchli 2009). The research results for Indonesia and the Philippines correspond to the early hypotheses stating that the firm age has significant negative effect on idiosyncratic risk.

The coefficient of determination that is used is the adjusted $R 2$. The results of the research in Indonesia has a value of 0.547541 , while in the Philippines amounted to 0.728932 for variable dependent idiosyncratic risk. The coefficient that have here a sense that changes in variable and idiosyncratic risk can be explained by both the variable board size, women, firm size, ROA, and firm age amounted to $54.7541 \%$, while the rest of $46.3333 \%$ is explained by variables other not included in this study for Indonesia. For the Philippines amounted to $72.8932 \%$ with the remainder of $28.2222 \%$ is explained by variables other are not included in the study this. 


\section{CONCLUSSION}

Based on the results of the analysis of 123 companies for Indonesia and 40 companies for the Philippines period of 2014-2018, then the board is simulated that the boards and women as independent variables and firm sizes, ROA, and firm age as control variables are significant effect on Idiosyncratic risk. The R2 and adjusted-R2 values for Indonesia are 0.641128 and 0.547541 , while the R2 and adjusted-R2 values for the Philippines are 0.788866 and 0.728932 . Thereby it can be concluded that the dependent variable Idiosyncratic Risk can be explained well by the independent variable of the board size, independent director, women, firm size, ROA, and firm age as the control variable with the results of statistical calculations showing $\mathrm{F}$ Indonesia and the Philippines count is 6.850629 and 13.16210 with a probability of $0.000000<$ 0.1 .

This research can be used as a reference for further research. The research also has limitations on the number of variables used, the research period, as well as selected objects. Therefore, it is expected for subsequent researchers to add to the variables previously used.

\section{ACKNOWLEDGMENTS}

Feel free to impress your gratitude to person(s) that help you in accomplish the research. Please keep the paragraph not more than 200 words.

\section{REFERENCES}

Adams, R. \& Funk, P. (2011). Beyond the glass ceiling: does gender matter?. Management Science, 58(2), 219-235.

Agarwal, R., \& M. Gort. (1996). The evolution of markets and entry, exit and survival of firms. Review of Economics and Statistics, 78, 489-498.

Agarwal, R., \& M. Gort. (2002). Firm product life cycles and firm survival. American Economic Review, 92, 184-190.

Asri, I. A. Y., \& Suwarta, I. K. (2014). Pengaruh faktor fundamental dan faktor ekonomi makro pada return saham perusahaan consumer good di Bursa Efek Indonesia. E-Jurnal Akuntansi, 353-370.

Becker, John R., Fred R. Kaen, Ahmad Etebari, \& Hans Baumann. (2010). Employees, firm size and profitabilityin U.S. manufacturing industries. Investment Management and Financial Innovations, 7(2).

Berggrun, L., Lizarzaburu, E., \& Cardona, E. (2016). Idiosyncratic volatility and stock returns: Evidence from the MILA. Research in International Business and Finance, 37, 422-434.

Bowman, E, H. (1982). Risk seeking by troubled firms. Sloan Management Review, 23(4): 33 $-42$.

Carney, M. (2005). Corporate governance and competitive advantage in family-controlled firms. Entrepreneurship Theory \& Practice, 29(3), 249-265.

Chakraborty, A., Gao, L., \& Sheikh, S. (2018). Corporate governance and risk in cross-listed and Canadian only companies. Management Decision.

Chong, Lee-Lee, Hway-Boon Ong, and Siow-Hooi Tan. (2018). Corporate risk-taking and performance in Malaysia: the effect of board composition, political connections and sustainability practices. Corporate Governance: The International Journal of Business in Society, 18(4), 635-654.

Croson, R. \& Gneezy, U. (2009). Gender differences in preferences. Journal of Economic Literature, 47(2), 448-474.

De Cabo, R.M., Gimeno, R. \& Nieto, M.J. (2012). Maria, gender diversity on European banks' board of directors. Journal of Business Ethics, 109(2), 145-162.

Dowling, M.M. \& Aribi, Z.A. (2012). Female directors and UK company acquisitiveness. International Review of Financial Analysis, 29(3), pp. 79-86. 
Eisenberg, T., Sundgren, S., \& Wells, T.W. (1998). Larger board size and decreasing firm value in small firms. Journal of Financial Economics, 48, 35-54.

Finkelstein, S. \& Hambrick, D.C. (1996). Strategic Leadership, West, Minneapolis, MN.

Florackis C., (2008). Agency costs and corporate governance mechanisms: evidence for UK firms. International Journal of Managerial Finance, 4(1), 37-59.

Ganto, Jullimursyida, et. al. (2008). Pengaruh kinerja keuangan perusahaan manufaktur terhadap return saham di bursa efek Indonesia. Media Riset Akuntansi, Auditing, dan Informasi, 8(1), 85-96.

Goddard, J., Tavakoli, M. \& Wilson, J. O. S. (2009). Sources of variation in firm profitability and growth. Journal of Business Research, 62, 495-508.

Hambrick, D.C. (1994). Top management groups: a conceptual integration and reconsideration of the team label, in Shaw, B.M. and Cummings, L. (Eds). Research in Organizational Behavior, JAI Press, Greenwich, CT, 171-214.

Jackson, S.E., Brett, J.F., Sessa, V.L., Cooper, D.M., Julin, J.A. \& Peyronnin, K. (1991). Some differences make a difference: individual dissimilarity and group heterogeneity as correlates of recruitment, promotions and turnover. Journal of Applied Psychology, 76, 675-89.

Jianakoplos, N.A. \& Bernasek, A. (1998). Are women more risk averse?. Economic Inquiry, 36(4), pp. 620-630.

Jensen, M, C \& Meckling, W, H. (1976). Theory of the firm: managerial behavior, agency costs and ownership structure. Journal of Financial Economics, 3(4), 305-360.

Kılıç, M. \& C. Kuzey., (2016). The effect of board gender diversity on firm performance: evidence from Turkey. Gender in Management: An International Journal, 31(7), 434 455.

Koerniadi, Hardjo, Chandrasekhar Krishnamurti, \& Alireza Tourani-Rad. (2014). Corporate governance and risk-taking in New Zealand. Australian Journal of Management, 39(2), 227-245.

Lee, M., Park, S., Lee, K., Lim, J., Kim, D., Kim, T., Shin, H., Lee, H. \& Lee, J. (2012). Economic prospect for the second half year of 2012, Series of Economic Prospect. Korea Institute of Finance, 2012 (2), 1-129.

Linck, J.S., Netter, J.M. \& Yang, T. (2008), The determinants of board structure. Journal of Financial Economics, 87(2), 308-328.

Loderer, Claudio \& Urs Waelchli. (2009). Firm age and performance. Journal of Economic Literature, 30, 20.

Mathew, S., Ibrahim, S., \& Archbold, S. (2016). Boards attributes that increase firm riskevidence from the UK. Corporate Governance, 16(2), 233-258.

Murhadi, W. R. (2013). Pengaruh idiosyncratic risk dan likuiditas saham terhadap return saham. Jurnal Manajemen dan Kewirausahaan, 15(1), 33-40.

Pa'stor, L. \& P. Veronesi. (2003). Stock valuation and learning about profitability. Journal of Finance, 58, 1749-89.

Pegels, C.C., Song, Y.I. \& Yang, B. (2000a). Management heterogeneity, competitive interaction groups, and firm performance. Strategic Management Journal, 21, 911-23.

Pegels, C.C., Song, Y.I. \&Yang, B. (2000b). The impact of managerial characteristics on strategic assets management capabilities. Team Performance Management, 12(7/8), 97-106.

Pervan, M., \& Višić, J. (2012). Influence of firm size on its business success. Croatian Operational Research Review, 3(1), 213-223.

Schulze, W. S., Lubatkin, M. H., \& Dino, R. N. (2002). Altruism, agency and the competitiveness of family firms. Managerial and Decision Economics, 23, 247- 259.

Schulze, W. S., Lubatkin, M. H., \& Dino, R. N. (2003). Toward a theory of agency and altruism in family firms. Journal of Business Venturing, 18, 473-490.

Siddiqui, M. F., Razzaq, N., Malik, F., \& Gul S. (2013). Internal Corporate Governance Mechanisms and Agency Cost: Evidence from Large KSE Listed Firms. European Journal of Business and Management, 5(23), 103-109.

Singh, M., \& Davidson, W. N. (2003). Agency Costs, Ownership Structure and Corporate 
Governance Mechanism. Journal of Banking and Finance, 27: 793-816.

Smith, K.G., Smith, K.A., Olian, J.D., Sims, H.P. Jr, O’Bannon, D.P. \& Scully, J.A. (1994). Top management team demography and process: the role of social integration and communication. Administrative Science Quarterly, 39, 412-38.

Smith, N., Smith, V., \& Verner, M. (2006). Do women in top management affect firm performance? A panel study of 2,500 Danish firms. International Journal of productivity and Performance management, 55(7), 569-593.

Truong, Th. T., \& Heaney, R. (2013). The determinants of equity agency conflicts between managers and shareholders: Evidence from Australia. Journal of Multinational Financial Management, 23, 314-326.

Ujiyantho, M. A., \& Pramuka, B. A. (2007). Mekanisme corporate governance, manajemen laba dan kinerja keuangan. Simposium Nasional Akuntansi X, 10(6), 1-26.

Ulupui, I. G. (2007). Analisis pengaruh rasio likuiditas, leverage, aktivitas, dan profitabilitas terhadap return saham (studi pada perusahaan makanan dan minuman dengan kategori industri barang konsumsi di BEJ). Jurnal IImiah Akuntansi dan Bisnis.

Yermack, D. (1996). Higher market valuation of companies with a small board of directors. Journal of Financial Economics, 40(2), 185-211.

Zhang, Cheng, Kee Cheok Cheong, \& Rajah Rasiah. (2018). Board independence, state ownership and stock return volatility during Chinese state enterprise reform. Corporate Governance: The International Journal of Business in Society, 18(2), 220-232. 